\title{
An exploration of design alternatives using dynamic thermal modelling software of an exemplar, affordable, low carbon residential development constructed by a registered so- cial landlord in a rural area of Wales
}

\begin{abstract}
Pembrokeshire Housing Association (PHA) a registered social landlord, based in Haverfordwest, Wales, UK, have developed six low carbon houses to meet Code for Sustainable Homes (CfSH) level four, as part of an exemplar scheme for the Welsh Government's CfSH pilot project. A tried and tested methodology was adopted in developing the PHA's pilot project houses that meant alternative low and zero carbon design methods were not fully explored. This paper employs comparative analysis to evaluate the final PHA scheme against other design options in order to assess alternative low energy approaches that might have been considered during the design of the project. Dynamic thermal modelling is used to assess and compare the design options in which the following are considered: building form; use of the thermal mass within the building fabric; design of the external envelope; and passive solar design strategies. The discussion considers the implications of the results with regard to approaches to low carbon design, as part of a doctoral research project, by the lead author on to develop innovative, affordable, low carbon housing in rural areas of Wales, UK.
\end{abstract}

\section{Background}

In 2010 Pembrokeshire Housing Association (PHA) completed a development of six two bedroom, semi-detached houses on Britannia Drive, in Pembrokeshire, west Wales, UK, built to the Code for Sustainable Homes level 4. The project was developed as part of the Welsh government's Code for Sustainable Homes (CfSH) pilot project to promote the construction of low and zero carbon housing through the Registered Social landlord (RSL) framework (Welsh Government 2011). The Britannia Drive design team took the decision to use a tried and tested methodology for the design and construction of the houses and utilised photovoltaic panels to meet the requirements for $\mathrm{CfSH}$ code level four.

The use of a tried and tested methodology meant that alternative design options for the low carbon design of the houses were not fully examined and this provides research opportunities to explore alternative approaches. In addition, dynamic 
thermal modelling was not used to examine the energy performance of the design. The fact that design options were not explored and dynamic thermal modelling was not used on this scheme provides opportunities to assess the thermal performance of different passive design approaches through dynamic thermal modelling.

\section{Methodology}

Dynamic thermal modelling predicts the energy performance of buildings using mathematical models to determine the interplay of heat exchange (Jankovic 2012). Dynamic thermal modelling software is frequently used to provide a prediction of the final energy usage of a scheme based on range of inputs including local climate, patterns of occupancy, building geometry, and building fabric (Morbitzer et al. 2001). However, the aim of this study was not to predict or compare the energy efficiency of the built project against a model, but rather to create variations of a control model, based on the as-built project; to assess design solutions with the potential to minimise energy consumption for space heating.

A comparative analysis approach was used whereby different design options were benchmarked against the original scheme rather than against an absolute standard, such as a representative dwelling built to a zero carbon standard (Bryman 2008; Creswell and Clark 2011). The disadvantage of the comparative analysis approach was that it was difficult to set the building design options within the broader context of aspirations by the British and Welsh Governments to develop zero carbon dwellings (Welsh Assembly Government 2009). However, the use of comparative analysis meant that design solutions developed for the study would be relevant to PHA's current approach and would not significantly deviate from the affordability and build-ability of the original scheme.

Two studies were undertaken; one exploring the design of individual dwellings, and a second investigating alternative approaches to the development of all six residential units. The first study investigated the impact of upgrades and adjustments to building fabric, such as introducing thermal mass, providing additional glazing on the south façade and improving the u-value of the building fabric. For the first study, the physical shape of the building, such as plan form and overall massing was not adjusted. The second study investigated the impact of developing the dwellings as a terrace rather than semi-detached houses. For this second set of studies the buildings' form was adjusted; however, the floor area of the original scheme was maintained as a constant, since any significant increase in floor area would undermine the affordability of any alternatives and any reduction would reduce the ability to compare results.

The designs from these two studies with the lowest sensible heating load were then amalgamated into two final schemes. These two final schemes represented optimum solutions, within the scope of the study, with regard to reducing sensible heating load and maintaining affordability. 


\section{Climate, Heating and Cooling and Occupancy Profiles}

The site for Britannia Drive is located in Pembroke Dock, in Pembrokeshire; therefore Aberporth Example Weather Year was used as the weather file because it provided a data set relevant to the location in west Wales. Weather files are used by dynamic thermal modelling software to provide a context for thermal calculations and an Example Weather Year matches the characteristics of a year to the average monthly values for a number of years of data (University of Exeter 2010).

A continuous occupancy profile, whereby the property would be considered occupied twenty-four hours, a day was adopted for these studies for two reasons. Firstly it was decided to minimise the multiple independent variables where possible. Secondly from discussions with PHA staff it was apparent that near continuous occupancy is not uncommon in social housing. However, future models will be calibrated with data from thermal monitoring of PHA's properties to allow occupancy profiles to be based on actual tenancy occupancy patterns.

With regard to annual heating profiles the heating period was set from $1^{\text {st }}$ September to $30^{\text {th }}$ April. A heating set point was set at 19 degrees centigrade $\left({ }^{\circ} \mathrm{C}\right)$; thus, when internal temperatures fell below this threshold during the heating period the boiler was activated. The cooling set point was set at $22^{\circ} \mathrm{C}$; thus, when internal temperatures rose above this threshold from $1^{\text {st }}$ May to August $31^{\text {st }}$ cooling was provided by additional natural ventilation through opening windows.

\section{Building Geometry}

The design of the Britannia Drive development had the principle elevations on the north and south facades. A south façade with three windows faces the street, and a north façade with four windows faces the back garden and the east and west facades, while significant in area, contain no glazing (see figures 1 and 2 below). This north-south orientation was maintained for all of the models.

All of the projects were subjected to a Suncast analysis in the Integrated Environmental Solutions (IES) dynamic thermal modelling software package. This component of the software package takes account of building orientation and solar shading to calculate solar gain. PHA's design for the dwellings at Britannia Drive had windows located immediately under the eaves (see figure 1 below) and this design feature was accounted for in the models, to allow Suncast to analyse the effect of shading provided to windows by this feature (see figure 2 below).

Figure 1 (left) and Figure 2 (right)- Britannia Drive south elevation as-built, before installation of photovoltaic panels (left) and IES model north elevation (right).
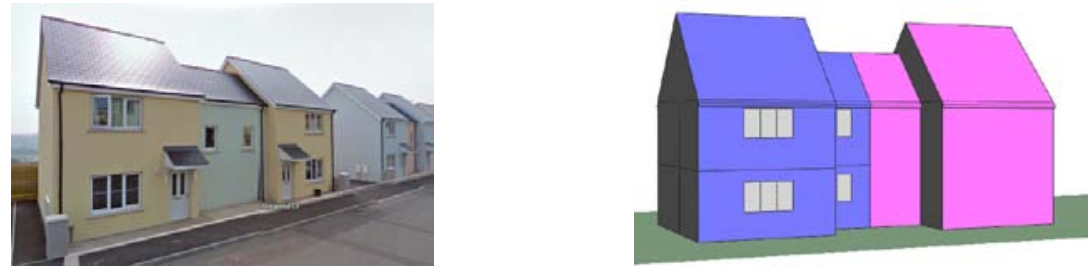


\section{Building Fabric Specification}

The make-up of a building's fabric can significantly affect a building's thermal performance, but not just with regard to thermal conductivity as in u-values, but also through its thermal mass (Tuohy et al. 2009). Four alternative fabric specifications were explored for this study with variations in u-values and thermal mass.

The first specification was based on PHA's standard wall construction, which consisted of $140 \mathrm{~mm}$ deep timber studs in-filled with mineral wool insulation for the inner skin and a rendered $100 \mathrm{~mm}$ blockwork outer skin which provided a uvalue of $0.21 \mathrm{~W} / \mathrm{m}^{2} \mathrm{~K}$ (see table 1 below). The second specification investigated the option of reversing the standard PHA building fabric, so that the blockwork element was on the inside of the insulation; thereby following passive solar design principles (Lowndes, 2008). Moreover, this does not increase the quantity of thermal mass within the building fabric; however it does affect the admittance value and decrement values. The admittance value is the ability of an element to exchange heat with the environment when subjected to cyclic variations in temperature and the decrement factor is the ratio between the cyclical temperature on the inside surface compared to the outside surface (The Concrete Centre 2009). Reversing the building fabric reduced the decrement factor, and increased the admittance value of the wall build-up by a factor of three (see table 1 below).

Table 1 - Britannia Drive as-built before, the installation of photovoltaic panels

\begin{tabular}{|l|c|c|c|c|}
\hline Building Fabric & $\begin{array}{l}\mathbf{U} \text { value } \\
\mathbf{W} / \mathbf{m}^{2} \mathbf{K}\end{array}$ & $\begin{array}{l}\text { Internal Heat } \\
\text { Capacity } \\
\mathbf{K J} / \mathbf{m}^{2} \mathbf{K}\end{array}$ & $\begin{array}{l}\text { Admit- } \\
\text { tance } \\
\text { Value }\end{array}$ & $\begin{array}{l}\text { Decre- } \\
\text { ment fac- } \\
\text { tor }\end{array}$ \\
\hline Standard External Wall & 0.21 & 19.95 & 1.45 & 0.41 \\
\hline Reversed Standard Wall & 0.21 & 134.07 & 4.37 & 0.34 \\
\hline PIR Insulation External Wall & 0.16 & 19.95 & 1.49 & 0.39 \\
\hline Reversed Wall w/ PIR insulation & 0.16 & 134.07 & 4.37 & 0.32 \\
\hline Standard Internal Wall & 0.37 & 11.97 & 0.90 & 0.99 \\
\hline Blockwork Internal Wall & 1.62 & 79.00 & 3.28 & 0.59 \\
\hline Standard First Floor Ceiling & 0.11 & 11.97 & 1.10 & 0.81 \\
\hline PIR Insulation First Floor Ceiling & 0.08 & 11.97 & 1.03 & 0.61 \\
\hline
\end{tabular}

Two further specifications considered the impact of replacing the mineral wool insulation between the interior wall studs with higher performance polyisocyanurate (PIR) insulation which is commonly used in the construction industry as a substitute for mineral wool insulation. This substitution of materials would have cost implications, as solid slab insulation can be as much as three times more expensive than an equivalent amount of mineral wool insulation (Davis Langdon 
2009). Nevertheless, it represented a means of upgrading PHA's building fabric while maintaining their current approach of using a $140 \mathrm{~mm}$ deep timber stud wall. As Table 1 (above) shows this substitution of materials raised u-values from 0.21 $\mathrm{W} / \mathrm{m}^{2} \mathrm{~K}$ to $0.16 \mathrm{~W} / \mathrm{m}^{2} \mathrm{~K}$, but did not significantly impact the admittance and decrement values. The fourth fabric specification combined a reversed building fabric with PIR insulation thus the exterior wall benefited from increased admittance and u-values.

\section{Results}

Two principle outputs were examined to gain an understanding of space heating and internal thermal comfort. Sensible heating load was used as the principle measure of operational energy and was considered both as a total measure and as a percentage reduction over the control building. With regard to thermal comfort, peak dry resultant temperature and number of hours over $25^{\circ} \mathrm{C}$ were taken as the most significant measures. Heating season temperatures were generally governed by the heating set point, which ensured that internal temperature were maintained within the comfort range; thus, it was only in summer ( $1^{\text {st }}$ May to $31^{\text {st }}$ August) that internal temperatures exceeded $25^{\circ} \mathrm{C}$. In addition, because summer cooling relied on natural ventilation provided by opening windows the houses are reliant on the building fabric to keep temperatures within the comfort range of $19^{\circ} \mathrm{C}$ to $25^{\circ} \mathrm{C}$.

\section{Modelling of the Individual Buildings}

An initial set of models (models A to $G$ in table 2) considered the impact of individual improvements such as increasing solar gain, increasing thermal mass to interior spaces or improving the insulation. The results from these initial models demonstrates that reversing the building fabric (as in model D) can provide modest (2.0\%) reductions in sensible heating load, reduce the peak internal temperature by $1.45^{\circ} \mathrm{C}$ and reduce the number of hours that the house was warmer than $25^{\circ} \mathrm{C}$ by 34 hours (see Table 2 and graph 1, below). Increasing the thermal mass with the addition of internal concrete blockwork walls in model $\mathrm{E}$ doubled this percentage reduction in heating load and eliminated internal temperatures above $25^{\circ} \mathrm{C}$ (see Table 2 and graph 1, below).

Increasing glazing on the south facade by $1.68 \mathrm{~m}^{2}$ (model B) produced a reduction in sensible heating load of just $0.6 \%$. Increasing the glazing also increased the number of hours where temperatures were above $25^{\circ} \mathrm{C}$ by 44 hours (see table 2 , and graph 1, below). Additional glazing (a further $1.68 \mathrm{~m}^{2}$ on the south façade, as in model C) aggravated the problems and produced a peak internal dry resultant temperature of $29.74^{\circ} \mathrm{C}, 2.19^{\circ} \mathrm{C}$ higher than the original model, (see Table 2, and graph 1, below). These results indicate that passive solar gain can be advantageous in providing 'free' space heating and reducing heating loads; however, in lightweight construction temperatures above comfort can occur when measures are not taken to address overheating. 
Graph 1 - Britannia Drive individual improvements peak dry resultant temperatures for main bedroom (south facing) during peak (external) dry bulb temperature week.
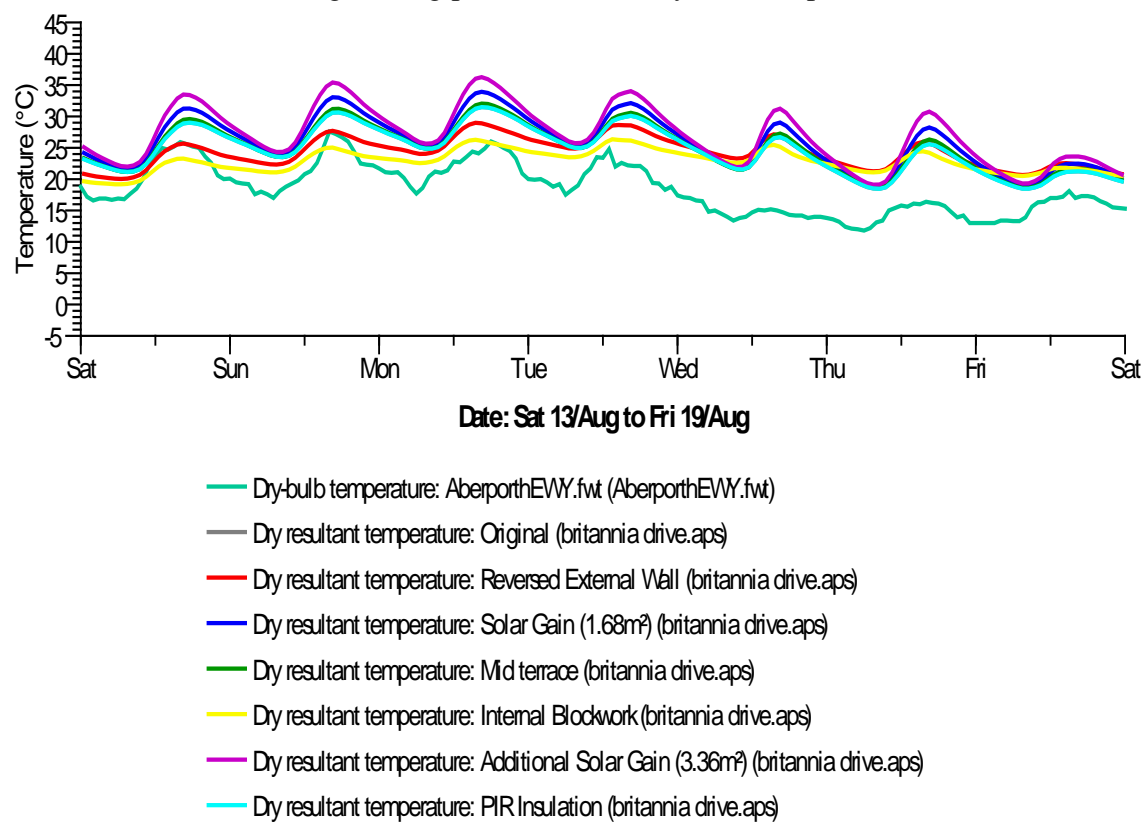

Table 2 - Britannia Drive single house, individual improvements table of results

\begin{tabular}{|c|c|c|c|c|c|}
\hline Scheme & $\begin{array}{l}\text { Annual } \\
\text { Sensible } \\
\text { Heating } \\
\text { Load } \\
\text { (MWh) }\end{array}$ & $\begin{array}{l}\text { \% reduc- } \\
\text { tion in sen- } \\
\text { sible heat- } \\
\text { ing load }\end{array}$ & $\begin{array}{l}\text { Peak in- } \\
\text { ternal } \\
\text { Tempera- } \\
\text { ture }\left({ }^{\circ} \mathrm{C}\right)\end{array}$ & $\begin{array}{l}\text { Time/Date } \\
\text { of peak in- } \\
\text { ternal } \\
\text { tempera- } \\
\text { ture }\end{array}$ & $\begin{array}{l}\text { No. of } \\
\text { hours } \\
\text { above } \\
25^{\circ} \mathrm{C}\end{array}$ \\
\hline $\begin{array}{l}\text { Original } \\
\text { (Model A) }\end{array}$ & 4.51 & 0.0 & 27.55 & $\begin{array}{r}17: 30 \\
15^{\text {th }} \text { Aug }\end{array}$ & 53 \\
\hline $\begin{array}{l}\text { Solar Gain }\left(1.68 \mathrm{~m}^{2}\right) \\
\text { (Model B) }\end{array}$ & 4.48 & 0.6 & 28.48 & $\begin{array}{r}17: 30 \\
15^{\text {th }} \text { Aug } \\
\end{array}$ & 97 \\
\hline $\begin{array}{l}\text { Additional Solar Gain } \\
\left(3.36 \mathrm{~m}^{2}\right)(\text { Model C) }\end{array}$ & 4.48 & 0.7 & 29.74 & $\begin{array}{r}17: 30 \\
15^{\text {th }} \text { Aug } \\
\end{array}$ & 209 \\
\hline $\begin{array}{l}\text { Reversed External Wall } \\
\text { (Model D) }\end{array}$ & 4.42 & 2.0 & 26.10 & $\begin{array}{r}16: 30 \\
15^{\text {th }} \text { Aug }\end{array}$ & 19 \\
\hline $\begin{array}{l}\text { Internal Blockwork } \\
\text { (Model E) }\end{array}$ & 4.32 & 4.0 & 24.84 & $\begin{array}{r}13: 30 \\
16^{\text {th }} \text { Aug } \\
\end{array}$ & 0 \\
\hline $\begin{array}{l}\text { Improved Insulation } \\
\text { (Model F) }\end{array}$ & 4.06 & 10.0 & 27.82 & $\begin{array}{r}17: 30 \\
15^{\text {th }} \text { Aug } \\
\end{array}$ & 69 \\
\hline $\begin{array}{l}\text { Mid Terrace } \\
\text { (Model G) }\end{array}$ & 4.03 & 11.0 & 27.86 & $\begin{array}{r}17: 30 \\
15^{\text {th }} \text { Aug }\end{array}$ & 78 \\
\hline
\end{tabular}


Graph 2 - Britannia Drive composite improvements peak dry resultant temperatures for main bedroom (south facing) during peak (external) dry bulb temperature week.

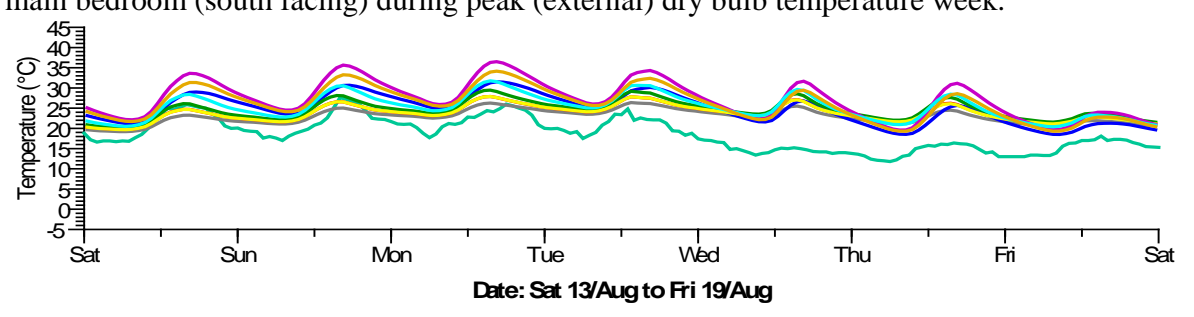

$$
\begin{aligned}
& \text { - Dry-bulb temperature: AberporthEWY.fut (AberporthEWY.fut) } \\
& \text { - Dry resultant temperature: PIR Insulation and Themal Mass(britannia drive.aps) } \\
& \text { - Dry resultant temperature: PIR Insulation, Themal Massand Solar Gain (1.68m²) (britannia drive.aps) } \\
& \text { - Dry resultant temperature: Original (britannia drive.aps) } \\
& \text { — Dry resultant temperature: Themal Massand Solar Gain (3.36m²) (britannia drive.aps) } \\
& \text { - Dy resultant temperature: Themal Massand Solar Gain (1.68m²) (britannia drive.aps) } \\
& \text { — Dry resultant temperature: PIR Insulation and Solar Gain (3.36m²) (britannia drive.aps) } \\
& \text { - Dry resultant temperature: PIR Insulation, Themal Massand Solar Gain (3.36m²) (britannia drive.aps) } \\
& \text { — Dry resultant temperature: PIR Insulation and Solar Gain (1.68m²) (britannia drive.aps) }
\end{aligned}
$$

\begin{tabular}{|c|c|c|c|c|c|}
\hline Scheme & $\begin{array}{l}\text { Annual } \\
\text { Sensible } \\
\text { Heating } \\
\text { Load } \\
\text { (MWh) }\end{array}$ & $\begin{array}{l}\text { \% reduc- } \\
\text { tion in sen- } \\
\text { sible heat- } \\
\text { ing load }\end{array}$ & $\begin{array}{l}\text { Peak in- } \\
\text { ternal } \\
\text { Tempera- } \\
\text { ture }\left({ }^{\circ} \mathrm{C}\right)\end{array}$ & $\begin{array}{l}\text { Time/Date } \\
\text { of peak in- } \\
\text { ternal } \\
\text { tempera- } \\
\text { ture }\end{array}$ & $\begin{array}{l}\text { No. of } \\
\text { hours } \\
\text { above } \\
25^{\circ} \mathrm{C}\end{array}$ \\
\hline $\begin{array}{l}\text { Original } \\
\text { (Model A) }\end{array}$ & 4.51 & 0.0 & 27.55 & $\begin{array}{r}17: 30 \\
15^{\text {th }} \text { Aug } \\
\end{array}$ & 53 \\
\hline $\begin{array}{l}\text { PIR Insulation } \\
\text { and Thermal Mass (Model } \\
\text { H) }\end{array}$ & 3.90 & 13.6 & 26.08 & $\begin{array}{r}13: 30 \\
16^{\text {th }} \text { Aug } \\
\end{array}$ & 21 \\
\hline $\begin{array}{l}\text { Thermal Mass and } \\
\text { Solar Gain }\left(1.68 \mathrm{~m}^{2}\right) \\
\text { (Model I) }\end{array}$ & 4.12 & 8.6 & 25.46 & $\begin{array}{r}13: 30 \\
16^{\text {th }} \text { Aug } \\
\end{array}$ & 10 \\
\hline $\begin{array}{l}\text { Thermal Mass and Addi- } \\
\text { tional Solar Gain }\left(3.36 \mathrm{~m}^{2}\right) \\
\text { (Model J) }\end{array}$ & 4.06 & 10.1 & 25.94 & $\begin{array}{r}13: 30 \\
16^{\text {th }} \text { Aug } \\
\end{array}$ & 20 \\
\hline $\begin{array}{l}\text { PIR Insulation and Solar } \\
\text { Gain }\left(1.68 \mathrm{~m}^{2}\right) \text { (Model K) }\end{array}$ & 4.04 & 10.5 & 28.5 & $\begin{array}{r}16: 30 \\
15^{\text {th }} \text { Aug }\end{array}$ & 105 \\
\hline $\begin{array}{l}\text { PIR Insulation and Solar } \\
\text { Gain }\left(3.36 \mathrm{~m}^{2}\right) \text { (Model L) }\end{array}$ & 4.04 & 10.5 & 29.14 & $\begin{array}{r}16: 30 \\
15^{\text {th }} \text { Aug } \\
\end{array}$ & 171 \\
\hline $\begin{array}{l}\text { PIR Insulation, Thermal } \\
\text { Mass and Solar Gain } \\
\left(1.68 \mathrm{~m}^{2}\right)(\text { Model M) }\end{array}$ & 3.76 & 17.9 & 25.94 & $\begin{array}{r}13: 30 \\
16^{\text {th }} \text { Aug } \\
\end{array}$ & 11 \\
\hline $\begin{array}{l}\text { PIR Insulation, Thermal } \\
\text { Mass and Solar Gain } \\
\left(3.36 \mathrm{~m}^{2}\right)(\text { Model } \mathrm{N})\end{array}$ & 3.71 & 18.0 & 25.97 & $\begin{array}{r}13: 30 \\
16^{\text {th }} \text { Aug }\end{array}$ & 22 \\
\hline
\end{tabular}

Table 3 - Britannia Drive single house, composite improvements table of results 
A second set of models (models $\mathrm{H}$ to $\mathrm{L}$ ) combined approaches such as additional south facing glazing and thermal mass to internal walls (models I and J); or thermal mass with higher performance insulation (model $\mathrm{H}$ ); or additional glazing on the south façade with higher performance insulation (Models K and L) (see Table 3). The most significant energy savings from this set of models was achieved through the combination of thermal mass with PIR insulation which not only reduced the sensible heating load of the original scheme by $13.6 \%$ and reduced the number of hours over $25^{\circ} \mathrm{C}$ and peak internal temperature to 21 hours (see table 3).

The results of table 3 indicate that the successful application of passive solar gain to reducing heating load is related to the provision of thermal mass both for addressing thermal discomfort but also for storing and releasing heat when required. This was demonstrated by the fact that the difference in heating reduction between the lightweight models of the initial study (models B and C) with $1.68 \mathrm{~m}^{2}$ and $3.36 \mathrm{~m}^{2}$ of extra glazing was $0.6 \%$ and $0.7 \%$; however, for the higher thermal mass composite models the respective reduction in sensible heating load was $8.6 \%$ (model I) and 10.1\% (model J) (see tables 2 and 3).

The use of higher performance insulation and passive solar gain without thermal mass achieved a $10.5 \%$ reduction in sensible heating load (see table 3 ). However, this approach produced a significant increase in internal temperatures over the original model with an additional 52 hours of temperatures in excess of $25^{\circ} \mathrm{C}$ over the control model (model A) (see table 3). Maintaining the lightweight building fabric, but increasing the glazing from $1.68 \mathrm{~m}^{2}$ to $3.36 \mathrm{~m}^{2}$ with higher performance insulation (see models $\mathrm{K}$ and $\mathrm{L}$ ) produced almost no decrease in sensible heating load and substantially increased the number of hours which internal temperatures were above $25^{\circ} \mathrm{C}$ to 171 hours (model L) (see table 3 ). These results suggest that there is an upper limit at which passive solar gain can be employed as a strategy for reducing space heating without the aid of thermal mass to store heat and moderate overheating.

Combining all of the passive strategies (models $\mathrm{M}$ and $\mathrm{N}$ ); thermal mass, additional glazing and insulation proved to be a useful strategy achieving a $17.9 \%$ and $18 \%$ reduction in sensible heating load compared to the control model (model A) (see table 3). The evidence suggests that the use of thermal mass successfully addressed any problems that might have occurred with regard to overheating as the internal temperatures and the number of hours where temperatures were above $25^{\circ} \mathrm{C}$ was lower than the original model at 11 hours in model $\mathrm{M}$ (see table 3 ).

\section{Modelling of the Site}

The second study took advantage of the fact that the gable ends on the east and west elevations did not have doors or windows and thus, in principle, could be butted against each other to create a terrace (model 2). In practice it would be problematic to abut the houses against each other due to the requirement for the 
provision of car parking spaces between the units; therefore, a terraced option was explored that utilised a shallow, but wide floor plate $(5.04 \mathrm{~m} \times 10 \mathrm{~m})$ for each dwelling, which located the houses in a $5.05 \mathrm{~m}$ zone between a front parking zone and rear gardens (model 3, figure 3). A further terraced model (model 4, figure 4) was developed based on a cube form, with a square floor plate $(7.1 \mathrm{~m} \times 7.1 \mathrm{~m})$, to examine the impact of further minimising the ratio of external surface area to internal volume.

Figure 3 (left) - IES visualisation of site model - narrow terrace south façade (model 3) Figure 4 (right) - IES visualisation of site model - compact terrace south façade (model 4)

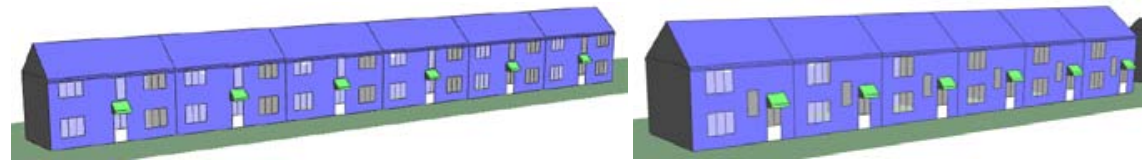

Table 4 - Britannia Drive site model table of results

\begin{tabular}{|c|c|c|c|c|c|}
\hline Scheme & $\begin{array}{l}\text { Annual } \\
\text { Sensible } \\
\text { Heating } \\
\text { Load } \\
\text { (MWh) }\end{array}$ & $\begin{array}{l}\text { \% Energy } \\
\text { Improve- } \\
\text { ment over } \\
\text { Base } \\
\text { Model }\end{array}$ & $\begin{array}{l}\text { Peak in- } \\
\text { ternal } \\
\text { Tempera- } \\
\text { ture }\left({ }^{\circ} \mathrm{C}\right)\end{array}$ & $\begin{array}{l}\text { Time/Date } \\
\text { of peak in- } \\
\text { ternal } \\
\text { tempera- } \\
\text { ture }\end{array}$ & $\begin{array}{l}\text { No. of } \\
\text { hours } \\
\text { above } \\
25^{\circ} \mathrm{C} \text { per } \\
\text { house }\end{array}$ \\
\hline $\begin{array}{l}\text { Original } \\
\text { (Model 1) }\end{array}$ & 27.05 & 0.0 & 28.56 & $\begin{array}{r}17: 30 \\
15^{\text {th }} \text { Aug } \\
\end{array}$ & 61 \\
\hline $\begin{array}{l}\text { Terrace } \\
\text { (Model 2) }\end{array}$ & 25.07 & 7.3 & 28.75 & $\begin{array}{r}17: 30 \\
15^{\text {th }} \text { Aug } \\
\end{array}$ & 73 \\
\hline Narrow Terrace (Model 3) & 21.4 & 20.9 & 30.17 & $\begin{array}{r}17: 30 \\
14^{\text {th }} \text { Sep }\end{array}$ & 303 \\
\hline $\begin{array}{l}\text { Compact Terrace (Model } \\
\text { 4) }\end{array}$ & 21.5 & 20.8 & 29.10 & $\begin{array}{r}17: 30 \\
15^{\text {th }} \text { Aug }\end{array}$ & 90 \\
\hline
\end{tabular}

The results from the first terrace model (model 1) indicated the benefit of minimising the external surface and produced a $7.3 \%$ saving in overall sensible heating load for all six houses (see table 4 above). Whilst, a compact form, minimising the external fabric surface area was one of the most significant factors in reducing heating it was the narrow terrace (model 3) that achieved the lowest annual sensible heating load of $21.5 \mathrm{MWh}$, slightly lower than the compact terrace (Model 4) with 21.4MWh. This result was due to the fact because of the shallow floor plan it was possible to put almost all of the windows on the south facade. This result confirms the findings from the composite models studies (models $\mathrm{H}$ to $\mathrm{N}$ ) which identified the benefits of combining passive design strategies; however, the fact that the majority of the windows were on the south façade meant that this design had significantly more hours (303 hours) where internal temperatures were above $25^{\circ} \mathrm{C}$ than the original design (see table 5). 


\section{Amalgamated Models}

A final set of options took the site model (model 3) and the individual building model (model $\mathrm{M}$ ) with the lowest sensible heating load to create an optimum solution within the limited context of the two studies. These amalgamated models (see $3 \mathrm{Ma}$ and $3 \mathrm{Mb}$ in table 5) combined a narrow compact terrace form with PIR insulation, thermal mass and $3.36 \mathrm{~m}^{2}$ of additional glazing. Amalgamated model $3 \mathrm{Mb}$ achieved a $40 \%$ decrease in sensible heating load for a mid-terrace option and model $3 \mathrm{Mb}$ achieved a 36\% decrease in sensible heating load for an end terrace over the original model (model A). However, this model did have siginifcant problems with regard to overheating with 348 hours where internal temperatures would be higher than $25^{\circ} \mathrm{C}$ and peak temperatures of $32.99^{\circ} \mathrm{C}$. Further development of the design would be required to address overheating issues to take advantage of energy and carbon savings without reducing thermal comfort.

Table 5 - Britannia Drive Amalgamated model results

\begin{tabular}{|l|c|l|l|l|l|}
\hline Scheme & $\begin{array}{l}\text { Sensible } \\
\text { Heating } \\
\text { Load } \\
\text { (MWh) }\end{array}$ & $\begin{array}{l}\text { \% Energy } \\
\text { Improve- } \\
\text { ment over } \\
\text { Base } \\
\text { Model }\end{array}$ & $\begin{array}{l}\text { Peak in- } \\
\text { ternal } \\
\text { Tempera- } \\
\text { ture }{ }^{(} \mathbf{C} \text { ) }\end{array}$ & $\begin{array}{l}\text { Time/Date } \\
\text { of peak in- } \\
\text { ternal } \\
\text { tempera- } \\
\text { ture }\end{array}$ & $\begin{array}{l}\text { No. of } \\
\text { hours } \\
\text { above } \\
\mathbf{2 5} \mathbf{C}\end{array}$ \\
\hline $\begin{array}{l}\text { Amalgamated End Terrace } \\
\text { (Model 3Ma) }\end{array}$ & 2.89 & 36 & 31.82 & $\begin{array}{c}15: 30 \\
14^{\text {th }} \text { Sep }\end{array}$ & 384 \\
\hline $\begin{array}{l}\text { Amalgamated Mid Terrace } \\
\text { (Model 3Mb) }\end{array}$ & 2.71 & 40 & 32.99 & $\begin{array}{r}15: 30 \\
14^{\text {th }} \text { Sep }\end{array}$ & 454 \\
\hline $\begin{array}{l}\text { Affordable End Terrace } \\
\text { (Model 3Ea) }\end{array}$ & 3.40 & 25 & 27.62 & $\begin{array}{r}15: 30 \\
14^{\text {th }} \text { Sep }\end{array}$ & 65 \\
\hline $\begin{array}{l}\text { Affordable Mid Terrace } \\
\text { (Model 3Eb) }\end{array}$ & 3.11 & 30 & 28.50 & $\begin{array}{r}15: 30 \\
14^{\text {th }} \text { Sep }\end{array}$ & 99 \\
\hline
\end{tabular}

An affordable solution was also developed that omitted PIR insulation, maintained the glazing at the same quantity as the original scheme but increased thermal mass (as model E). This design produced a reduction in sensible heating of $25 \%$ for an end terrace and $30 \%$ for a mid-terrace (see table 5 ). In addition, the peak internal temperature of $27.62^{\circ} \mathrm{C}$ for the end terrace was only $0.17^{\circ} \mathrm{C}$ higher than the original scheme, which indicates that this solution would not require significant design development to address overheating problems.

\section{Conclusion}

The study indicates that significant energy savings (25\% - 40\%) in sensible heating load can be achieved even on an exemplar low carbon project with little or no additional capital cost. Measures such as specifying thermal mass to internal walls, considering the ratio of external area to internal volume and the massing of 
the buildings on the site can provide considerable savings in heating load with apparently little or no addition to the capital cost of a project. The use of designs features to allow internal rooms to capture passive solar gain can also be used to reduce heating load; however it can be problematic with regard to maintaining thermal comfort unless measures to mitigate overheating (Orme et al. 2010) and store heat within the fabric are considered.

The study also indicates that overheating will increasingly become a problem as buildings become more become more effective at reducing sensible heating load through building form and fabric based approaches. Thus, considering measures to address overheating, such as the specification of thermal mass, as in this study, and perhaps ventilating strategies like night cooling or stack ventilation, will become more important in low carbon house design.

The study indicates the benefits of combining approaches rather than being overly reliant on one strategy; however the interplay of these approaches requires careful consideration to maintain reasonable levels of internal comfort and dynamic thermal modelling should be considered to investigate any potential issues. The results indicate that the application of thermal mass, passive solar gain, high levels of insulation and a terrace form should be considered to produce significant savings in energy in dwellings that comply with social housing design standards in Wales, UK.

\section{Acknowledgements}

The doctoral research project being undertaken by the first author is funded by Cardiff Metropolitan University, PHA and the Knowledge Economy Skills Scholarship which is supported by the European Social Fund through the European Union's Convergence programme and administered by the Welsh Government.

\section{References}

Bryman, A. 2008. Social research methods. Oxford University Press, Oxford, UK.

Creswell, J, W. Clark, V, L, P. 2011. Designing and conducting mixed methods research, $2^{\text {nd }}$ edition. Sage, London, UK.

Davis Langdon, 2009. Spons: Architects and Builders price book 2010, $134^{\text {th }}$ edition. Oxon, UK.

Jankovic, J., 2012. Designing Zero Carbon Buildings Using Dynamic Simulation Methods. Routledge, Oxon, UK.

Lowndes, S. 2008. Design for passive heating, Chapter 1.12. In: the Green Building Bible - Volume 1. Ed: Hall, K. Green Building Press, Llandysul, UK. 
Morbitzer, C., Strachen, P., Webster, J., Spires, B., Cafferty, D., 2001. Intergration of Building Simulation into the design process of an architecture Practice. Seventh International IBPSA Conference, Rio de Janeiro, Brazil, August 13-15, 2001. Available from [Accessed $25^{\text {th }}$ September 2011].

Orme, M., Palmer, J., Irving, S., 2010. Control of Overheating in Well-insulated Housing. Faber Maunsell Ltd. Available from: http://www.cibse.org/pdfs/7borme.pdf [Accessed $18^{\text {th }}$ July 2011].

The Concrete Centre, 2009. Thermal Mass Explained: Thermal Mass: what it is and how it's used [online]. Available from:

http://www.concretecentre.com/online_services/publication_library/publication_d etails.aspx?PublicationId=681 [Accessed $18^{\text {th }}$ July 2011].

Tuohy, P., McElroy, L., Johnstone, C., 2005. Thermal mass, Insulation and Ventilation in Sustainable Housing - an Investigation across climate and occupancy. Strathclyde: University of Strathclyde. Available from: http://www.esru.strath.ac.uk/Documents/05/bs05-paper-pt.pdf [Accessed $18^{\text {th }}$ July 2011].

University of Exeter, 2010. Weather Files for Current and Future Climate [online]. Exeter: University of Exeter. Available from:

http://emps.exeter.ac.uk/media/universityofexeter/schoolofengineeringmathematic sandphysicalsciences/research/cee/lchsmodule1notes/Weather_Files.pdf [Accessed $12^{\text {th }}$ December 2011].

Welsh Government, 2011. Code for Sustainable Homes Pilot Project Interim Report February 2011. Cardiff: Welsh Government.

Welsh Assembly Government (WAG), 2009. Ministerial Planning Policy Statement - Planning for Sustainable Buildings. Cardiff: Welsh Assembly Government. 